Urban Water Systems \& Floods II 133

\title{
MORPHODYNAMIC ANALYSIS OF THE TUCCIO RIVER, SOUTH CALABRIA, ITALY
}

\author{
PAOLO FANTINO GERIA, GIANDOMENICO FOTI \& PIERFABRIZIO PUNTORIERI \\ DICEAM Department, Mediterranea University of Reggio Calabria, Italy
}

\begin{abstract}
The paper describes a case study of the Tuccio River, which models and analyses its discharge, sediment transport and morphological evolution, and also identifies the possible causes of evolutionary and flooding phenomena. The Tuccio River is situated in the southern extremity of Calabria, on the Ionian coast, about $30 \mathrm{~km}$ from Reggio Calabria. Adjacent to the river there is a town (Melito Porto Salvo), an aqueduct, and varied economic activity, most of which is related to agriculture and breeding. This is an interesting case study because the riverbed has displayed several morphological changes, many of which were recent and related to the construction of hydraulic works. The entire riverbed study area was divided into two sub-sections. The downstream sub-section is about $3.5 \mathrm{~km}$ long, it is heavily anthropised and has an elevation from the riverbed. Flooded areas were evaluated for this section. The second sub-section is located about $10 \mathrm{~km}$ upstream from the river mouth, its length is over $3 \mathrm{~km}$ long and it is characterised by an erosive phenomena. The sediment transport in the section was modelled and the modelling became complex. In fact, the following software was used: MapWindow (to characterise the river basin), Google Earth Pro, QGIS and the GPS Visualizer application (for the reconstruction of the DEM), HEC-HMS (for hydrological modelling), HEC-RAS2D (for hydraulic and sediment transport modelling). From the results of the HEC-RAS2D modelling it was possible to observe that in the mountain section, 50,000 t/year were eroded on average. Moreover, a significant percentage of this material was deposited downstream. This situation, together with the presence of hydraulic structures, caused an elevation of the river bed, with an increase in flood risk. In conclusion, it is possible to state that large-scale modelling as described above is particularly useful for an effective understanding of river dynamics.
\end{abstract}

Keywords: flood, modelling, sediment transport, erosive phenomena, flooding risk.

\section{INTRODUCTION}

The increase in anthropogenic pressure observed in Italy over the last 50 years has increased the vulnerability of the territory under the action of natural events such as floods [1]-[3], debris flow [4], storms [5], [6] and coastal erosion [7], [8]. In fact, the increase in anthropogenic pressure has mainly resulted in an increase in soil waterproofing [9], with a consequent reduction in hydrological losses and an increase in river discharge with the same rainfall event. Moreover, the increase in anthropogenic pressure has altered the river dynamics due to the construction of hydraulic structures which interfere with fluvial dynamics such as levees, dams [10], [11], inert drains from river beds, and soil erosion by water [12], [13]. The alterations of the river dynamics, and therefore of the river transport, has also modified coastal dynamics [14]. Indeed, the shoreline position is an important factor in coastal dynamics [15]-[17] and is related to natural and anthropogenic factors [18], [19]. The most important anthropogenic factors [20] are the construction of buildings, infrastructure, ports and coastal defence works [21]-[27]. Among the natural factors, the most important are the action of wave motion [28]-[32] and the interaction between longshore and river transport [33]-[37]. Therefore, an accurate knowledge of river [38] and coastal morphodynamics [39], [40] and of its causes [41]-[43] are important for river and coastal zone planning and management [44].

This paper describes a case study related to the terminal area of the Tuccio River, located in the southern part of Calabria (Italy). In this paper the discharge, the sediment transport and 
the morphological evolution of the riverbed are analyzed and possible causes of these phenomena are also identified.

\section{SITE DESCRIPTION}

The study area is situated in the southern part of Calabria (Italy), and its mouth is on the Ionian Sea near Melito Porto Salvo, a town $30 \mathrm{~km}$ distant from Reggio Calabria (for this reason the river is also called the "Melito River"). An aqueduct and various economic activities are also situated near the river, most of which are related to agriculture and breeding. The river has undergone several morphological changes, both longitudinally and transversally, most of which have been concentrated in the last twenty years and are related to the construction of various types of hydraulic works (weirs, embankments). These structures have caused both erosion and elevation of the riverbed. For example, such erosion can be seen at the bridge piers in Prunella (Fig. 1). Moreover, it is possible to observe the collapse of an embankment (Fig. 2) and the elevation of the riverbed that has exceeded the altitude of the inhabited area in Pallica (Fig. 3).

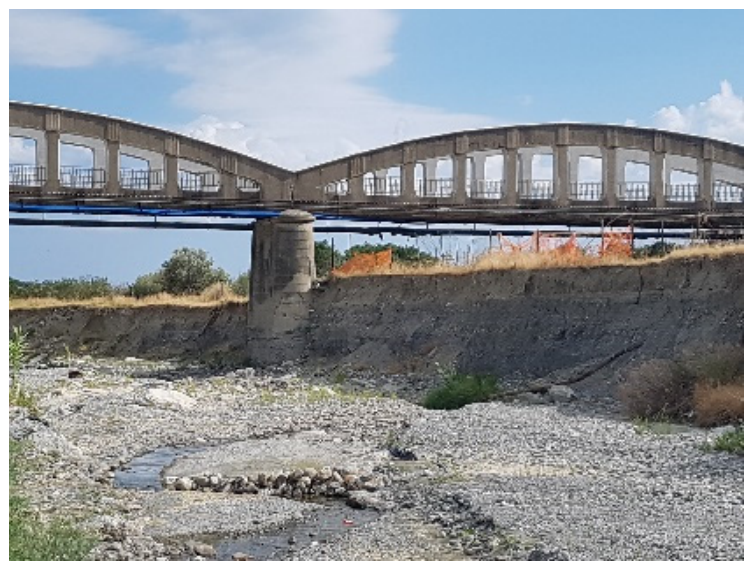

Figure 1: The Tuccio River: erosion at bridge piers in Prunella.

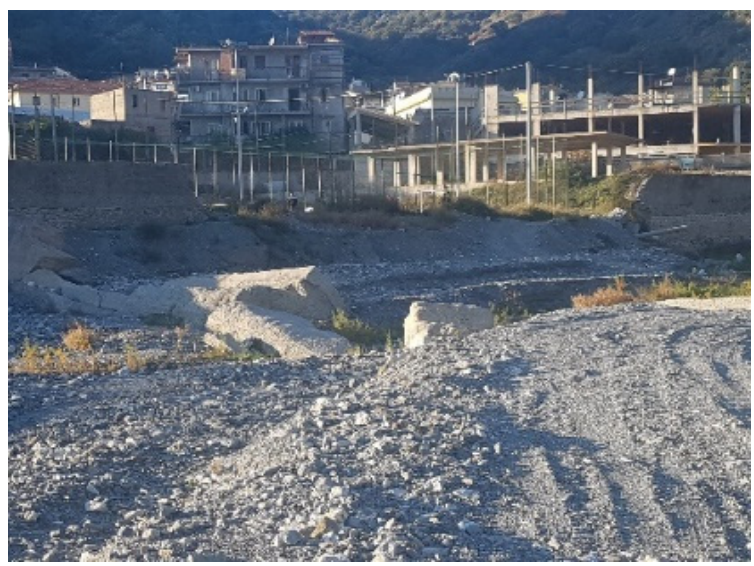

Figure 2: The Tuccio River: collapse of an embankment. 


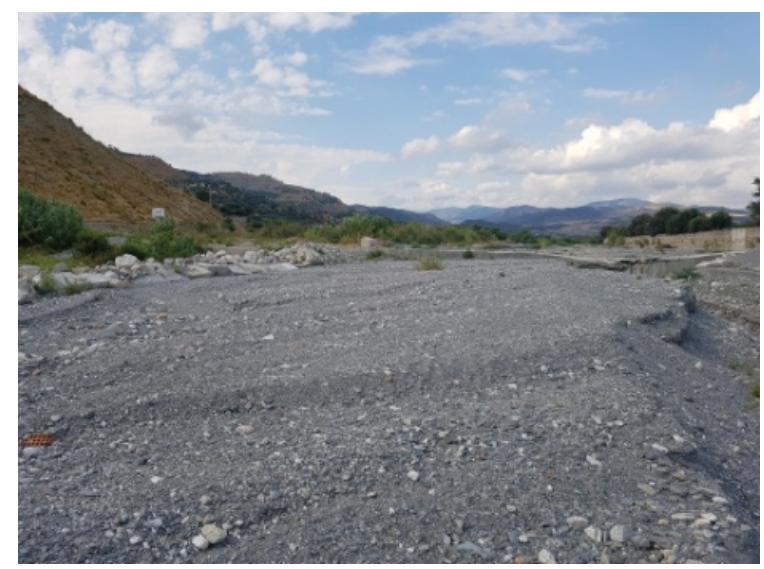

Figure 3: The Tuccio River: elevation of the riverbed that has exceeded the altitude of the inhabited area in Pallica.

\section{MODELLING}

The discharge, the sediment transport and the morphological evolution of the Tuccio River were modelled using HEC-RAS 2D and the relative sediment transport module. Before carrying out this modelling it was first necessary to identify and morphometrically characterise the catchment area using Map Window, to reconstruct the DEM using the procedure described below, and to perform hydrological modelling with HEC-HMS.

\subsection{Catchment area properties and DEM reconstruction}

The identification and morphometric characterisation phase of the catchment area was carried out by starting from the data available in the OpenData section of the Geoportal of the Calabria Region (http://geoportale.regione.calabria.it/) using Map Window and its Watershed Delineation plugin. The results obtained are shown in Fig. 4 and in Table 1.

The DEM reconstruction procedure, to be used as input for HEC-RAS modelling, involved various software and applications. In particular, starting from the satellite images available, two DEMs were created using the Google Earth Pro Path function, which related to two different time periods, being October 2005 and September 2017. The points identified were then processed with the Elevation function of the GPS Visualizer application, in order to assign the relative coordinates and elevations to each point. These points were then imported into QGIS in order to create a unique DEM for each time period using a triangular interpolation function. The results obtained are shown in Fig. 5.

Table 1: Morphometric parameters of the Tuccio River basin.

\begin{tabular}{|l|l|}
\hline Parameter & Value \\
\hline Area $\left(\mathrm{Km}^{2}\right)$ & 80.0 \\
\hline Perimeter $(\mathrm{Km})$ & 59.0 \\
\hline Main stream length $(\mathrm{Km})$ & 30.2 \\
\hline Average height $(\mathrm{m})$ & 673.2 \\
\hline Average slope $(\%)$ & 36.7 \\
\hline Horton's order & 6 \\
\hline
\end{tabular}




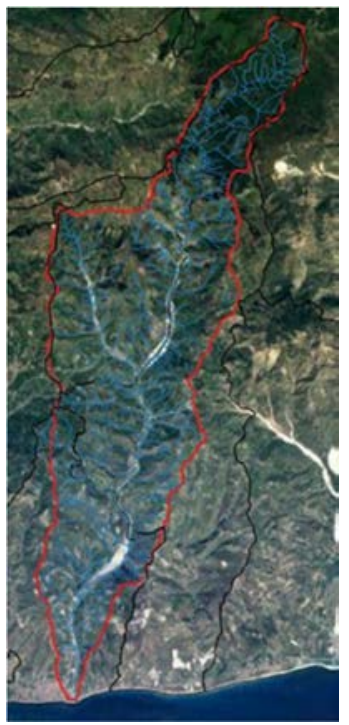

Figure 4: The Tuccio River basin.
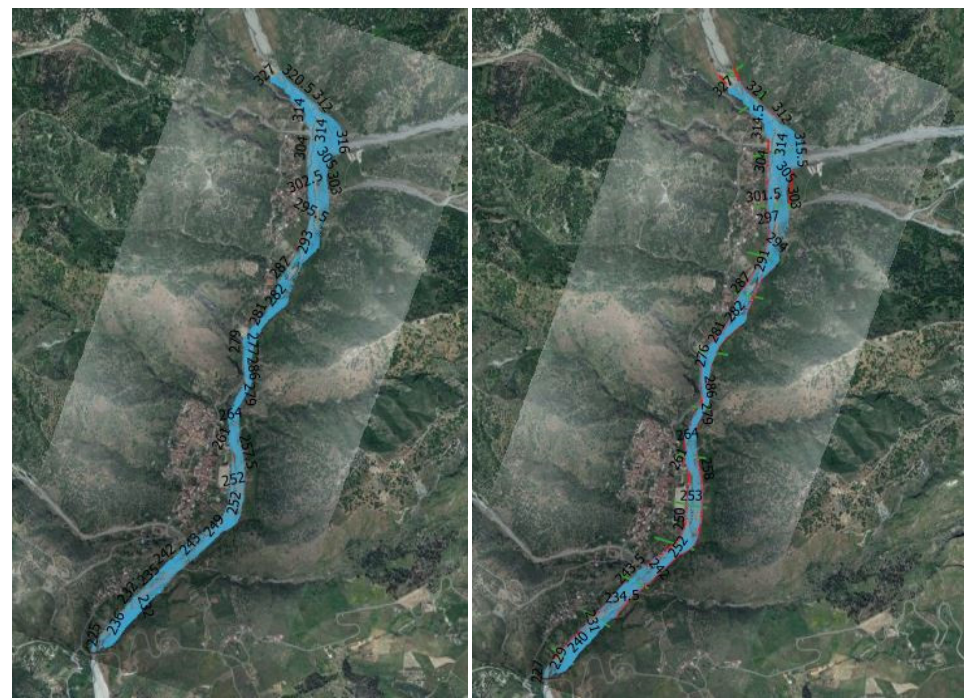

Figure 5: On the left there is the DEM of 2005, on the right that of 2017.

\subsection{Hydrological modelling}

The hydrological modelling was carried out using HEC-HMS in order to estimate the design hydrographs with a return period of 200 years, starting from the rainfall data recorded by the three gauges (Melito Porto Salvo, Roccaforte del Greco, Croce San Lorenzo) present in the Tuccio River basin or near it (Fig. 6 and Table 2). For each station, the rainfall depth-duration curve was obtained by analysing the annual rainfall maxima of 1, 3, 6, 12 and 24 hours. The 
rainfall depth-duration curve of the entire basin was obtained by taking into account the influence area of each station and assessed by the Thiessen polygon method. The results obtained are shown in Fig. 7.

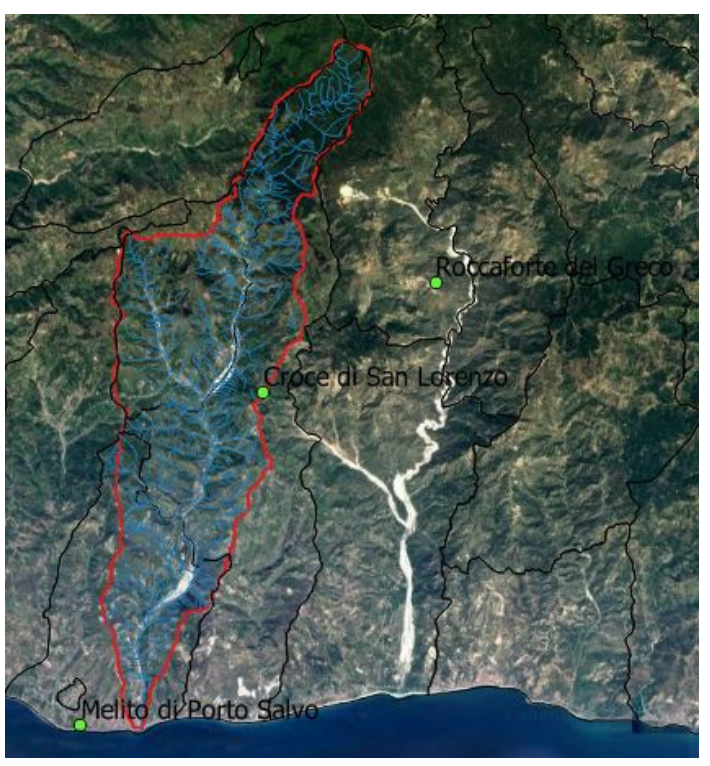

Figure 6: Gauges located in or near the Tuccio River basin.

Table 2: Gauges featured.

\begin{tabular}{lccc}
\hline Gauges & Elevation $(\mathrm{m})$ & Years available & Weight $(\%)$ \\
\hline Croce San Lorenzo & 656 & 36 & 16 \\
Melito Porto Salvo & 10 & 17 & 66 \\
Roccaforte del Greco & 937 & 13 & 18 \\
\hline
\end{tabular}

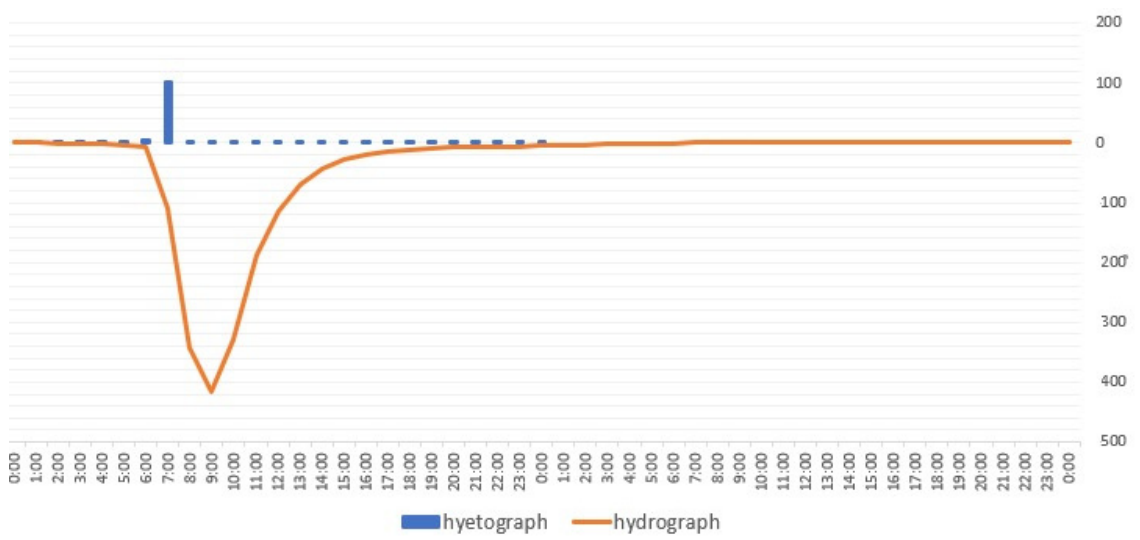

Figure 7: Design hyetograph and hydrograph of the Tuccio River basin. 


\subsection{Hydraulic and sediment transport modelling}

The study area was divided into two parts, one near the river mouth with a length of about $3.5 \mathrm{~km}$. This part is the most anthropised and mainly flood areas were studied (Fig. 8). The second part is located about $10 \mathrm{~km}$ upstream from the mouth and is over $3 \mathrm{~km}$ long. This part is the one most subject to morphological changes and mainly sediment transport was modelled (Fig. 9). For the modelling of both areas, HEC-RAS 2D was used and the river geometry was obtained using HEC-RAS Utilities, a Map Window plugin. In particular, this plugin generated the shapefiles of the cross-sections and characteristic elements (Channel, Banks, Levees) using the DEMs described above. To identify the flood areas, the RASMapper application was used. Regarding the sediment transport, the evolution trend of the river was identified using the SIAM (System Impact Assistant Model) model. Furthermore, the equilibrium profile was identified using the tangential effort method (Stable Channel Design).

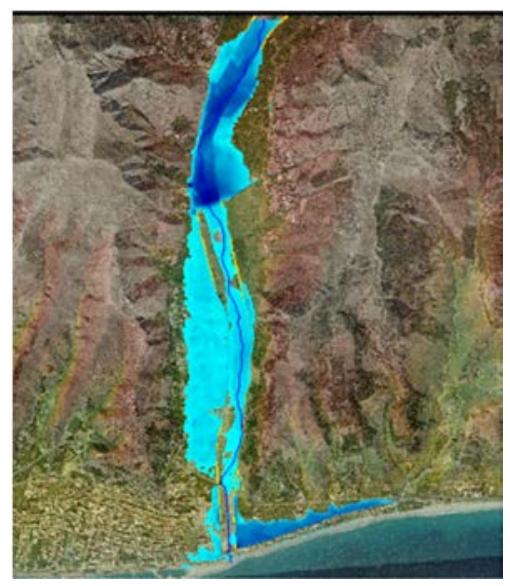

Figure 8: Flooding areas of the Tuccio River basin.

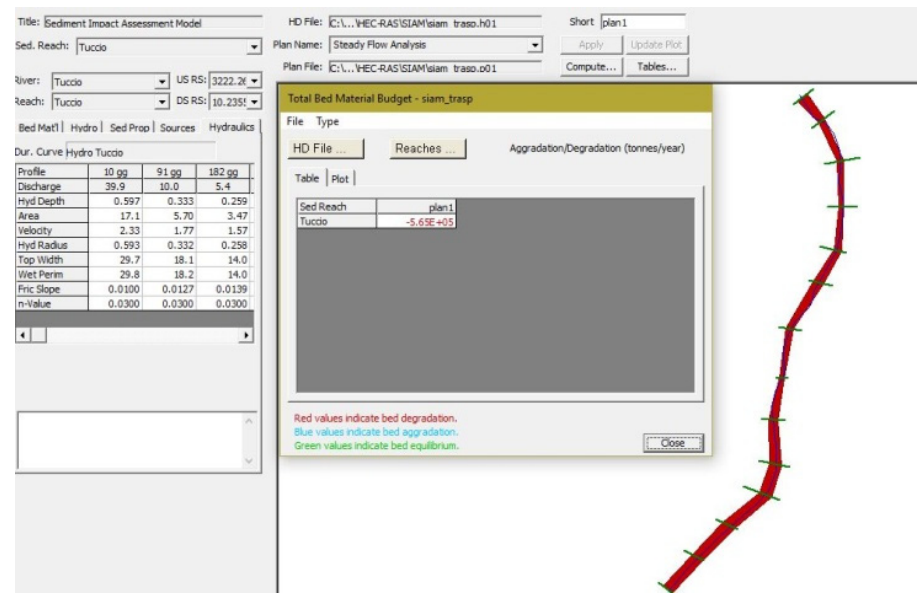

Figure 9: Sediment transport of the Tuccio River basin. 


\section{CONCLUSIONS}

The paper describes a case study of the Tuccio river whose discharge, sediment transport and morphological evolution were modelled and analysed, and the possible causes of evolutionary and flooding phenomena were identified. The river is an interesting case study as it has undergone several morphological changes both longitudinally and transversally, most of which have been concentrated in the last twenty years and are related to the construction of various types of hydraulic works, weirs, embankments, etc.

The study area was divided into two parts, one near the river mouth with a length of about $3.5 \mathrm{~km}$. This part was the most anthropised and mainly flood areas were studied. The second part is located about $10 \mathrm{~km}$ upstream from the mouth and is over $3 \mathrm{~km}$ long. This part is the one most subject to morphological changes and mainly sediment transport was modelled.

The modelling reached a high level of complexity and required the joint use of different software and applications: Map Window to identify and morphometrically characterise the catchment area, Google Earth Pro, QGIS and the GPS Visualizer application to reconstruct the DEM, HEC-HMS to perform hydrological modelling, and HEC-RAS 2D to perform hydraulic and sediment transport modelling.

From the results of the hydraulic modelling it is possible to observe that in the terminal part of the Tuccio river floods can occur near the inhabited areas. In this part the riverbed is at higher altitudes than the adjacent territories, and this increases flood risk. The modelling of solid transport showed that in the upstream section over 50,000 t/year was lost on average, causing a lowering of the riverbed. This situation can also be observed by comparing the two DEMs. A significant percentage of the eroded material was deposited downstream and this contributed to the emergence of the phenomena described above.

In conclusion, studies and modelling carried out on small portions of a river basin, without taking into account the other river basin parts, can lead to partial or misleading results of the fluvial dynamics. It is therefore necessary to perform basin scale studies using hydraulic, hydrological and morphological modelling, as is the case described in this paper.

\section{REFERENCES}

[1] Fiori, E. et al., Analysis and hindcast simulations of an extreme rainfall event in the Mediterranean area: The Genoa 2011 case. Atmospheric Research, 138, pp. 13-29, 2014.

[2] Barbaro, G., Petrucci, O., Canale, C., Foti, G., Mancuso, P. \& Puntorieri, P., Contemporaneity of floods and storms. A case study of Metropolitan Area of Reggio Calabria in Southern Italy. Proceedings of New Metropolitan Perspectives (NMP), Reggio Calabria, Italy, 2018.

[3] Scionti, F., Miguez, M.G., Barbaro, G., De Sousa, M.M., Foti, G. \& Canale, C., An integrated methodology for urban flood risk mitigation: The case study of Cittanova (Italy). Journal of Water Resources Planning and Management, in press.

[4] Destro, E. et al., Coupled prediction of flash flood response and debris flow occurrence: Application on an alpine extreme flood event. Journal of Hydrology, 558, pp. 225-237, 2018.

[5] Arena, F., Barbaro, G. \& Romolo, A., Return period of a sea storm with at least two waves higher than a fixed threshold. Mathematical Problems in Engineering, pp. 1-6, 2013.

[6] Boudet, L., Sabatier, F. \& Radakovitch, O., Modelling of sediment transport pattern in the mouth of the Rhone delta: Role of storm and flood events. Estuarine, Coastal and Shelf Science, 198, pp. 568-582, 2017. 
[7] Komar, P.D., Coastal erosion-underlying factors and human impacts. Shore \& Beach, 68(1), pp. 3-16, 2000.

[8] Barbaro, G., Foti, G. \& Sicilia, C.L., Coastal erosion in the south of Italy. Disaster Advances, 7, pp. 37-42, 2014.

[9] ISPRA, Dissesto idrogeologico in Italia: pericolosità e indicatori di rischio. Rapporto No. 233, 2015 (in Italian).

[10] Zema, D.A., Bombino, G., Boix-Fayos, C., Tamburino, V., Zimbone, S.M. \& Fortugno, D., Evaluation and modeling of scouring and sedimentation around check dams in a Mediterranean torrent in Calabria, Italy. Journal of Soil and Water Conservation, 69(4), pp. 316-329, 2014.

[11] Fortugno, D. et al., Adjustments in channel morphology due to land-use changes and check dam installation in mountain torrents of Calabria (southern Italy). Earth Surface Processes and Landforms, 42(14), pp. 2469-2483, 2017.

[12] Grimm, M., Jones, R.J.A. \& Montanarella, L., Soil Erosion Risk in Europe. European Soil Bureau Research Report, EUR 19939 EN. Office for Official Publications of the European Communities: Luxembourg, 2002.

[13] Grimm, M., Jones, R.J.A. \& Montanarella, L., Soil Erosion Risk in Italy: A Revised USLE Approach. European Soil Bureau Research Report No. 11, EUR 20677 EN. Office for Official Publications of the European Communities: Luxembourg, 2003.

[14] Perez-Arlucea, M., Mendez, G., Clemente, F., Nombela, M., Rubio, B. \& Filgueira, M., Hydrology, sediment yield, erosion and sedimentation rates in the estuarine environment of the Ria de Vigo, Galicia, Spain. Journal of Marine Systems, 54, pp. 209-226, 2005.

[15] Boak, E.H. \& Turner, I.L., Shoreline definition and detection: A review. Journal of Coastal Research, 21(4), pp. 688-703, 2005.

[16] Maiti, S. \& Bhattacharya, A.K., Shoreline change analysis and its application to prediction: A remote sensing and statistics-based approach. Marine Geology, 257(14), pp. 11-23, 2009.

[17] Barbaro, G., Fiamma, V., Barrile, V., Foti, G. \& Ielo, G., Analysis of the shoreline changes of Reggio Calabria (Italy). International Journal of Civil Engineering and Technology, 8(10), pp. 1777-1791, 2017.

[18] Morton, R.A., Miller, T.A. \& Moore, L.J., National Assessment of Shoreline Change: Part 1: Historical Shoreline Changes and Associated Coastal Land Loss along the US Gulf of Mexico. US Geological Survey Open-File Report 1043, 2004.

[19] Syvitski, J.P.M. \& Saito, Y., Morphodynamics of deltas under the influence of humans. Global and Planetary Change, 57(3-4), pp. 261-282, 2007.

[20] Manca, E., Pascucci, V., Deluca, M., Cossu, A. \& Andreucci, S., Shoreline evolution related to coastal development of a managed beach in Alghero, Sardinia, Italy. Ocean and Coastal Management, 85, pp. 65-76, 2013.

[21] Barbaro, G., A new expression for the direct calculation of the maximum wave force on vertical cylinders. Ocean Engineering, 34, pp. 1706-1710, 2007.

[22] Barbaro, G. \& Foti, G., Shoreline behind a breakwater for wave energy absorption in Reggio Calabria: Comparison between theoretical models and experimental data. Proceedings of the Second International Conference on Physical Coastal Processes, Management and Engineering, Naples, Italy, pp. 237-248, 2011.

[23] Barbaro, G., Saline Joniche: A predicted disaster. Disaster Advances, 6, pp. 1-3, 2013.

[24] Barbaro, G. \& Foti, G., Shoreline behind a breakwater: comparison between theoretical models and field measurements for the Reggio Calabria sea. Journal of Coastal Research, 29, pp. 216-224, 2013. 
[25] Barbaro, G., Foti, G. \& Sicilia, C.L., Wave forces on upright breakwater, evaluation and case study. Disaster Advances, 6, pp. 90-95, 2013.

[26] Poeta, G., Conti, L., Malavasi, M., Battisti, C. \& Acosta, A.T.R., Beach litter occurrence in sandy littorals: The potential role of urban areas, rivers and beach users in central Italy. Estuarine, Coastal and Shelf Science, 181, pp. 231-237, 2016.

[27] Miduri, M., Foti G. \& Puntorieri P., Impact generated by Marina of Badolato (Italy) on adjacent coast. Proceeding of the 13th International Congress on Coastal and Marine Sciences, Engineering, Management and Conservation (MEDCOAST), Mellieha, Malta, 2017.

[28] Barbaro, G., Estimating design wave for offshore structures in Italian waters. Proceedings of the Institution of Civil Engineering, Maritime Engineering, 164, pp. 115-125, 2011.

[29] Boccotti, P., Arena, F., Fiamma, V., Romolo, A. \& Barbaro, G., Estimation of mean spectral directions in random seas. Ocean Engineering, 38, pp. 509-518, 2011.

[30] Barbaro, G., Foti, G. \& Malara, G., Set-up due to random waves: influence of the directional spectrum. Proceedings of the 30th International Conference on Ocean, Offshore and Artic Engineering, Rotterdam, The Netherlands, 2011.

[31] Barbaro, G., Foti, G. \& Malara, G., Set-up due to random waves: influence of the directional spectrum. International Journal of Maritime Engineering, 155, pp. A105A115, 2013.

[32] Boccotti, P., Wave Mechanics and Wave Loads on Marine Structures. Elsevier BH: Oxford, 2015.

[33] Barbaro, G., Foti, G., Mandaglio, G., Mandaglio, M. \& Sicilia, C.L., Estimate of sediment transport capacity in the basin of the Fiumara Annunziata (RC). Rendiconti Online Società Geologica Italiana, 21(1), pp. 696-697, 2012.

[34] Sicilia, C.L., Foti, G. \& Campolo, A., Protection and management of the Annunziata river mouth area (Italy). Journal of Air, Soil and Water Research, 6, pp. 107-113, 2013.

[35] Barbaro, G., Foti, G., Sicilia, C.L. \& Malara, G., A formula for the calculation of the longshore sediment transport including spectral effects. Journal of Coastal Research, 30, pp. 961-966, 2014.

[36] Tomasicchio, G.R., D’Alessandro, F., Barbaro, G., Musci, E. \& De Giosa, T.M., Longshore transport at shingle beaches: an independent verification of the general model. Coastal Engineering, 104, pp. 69-75, 2015.

[37] Borrello, M.M., Foti, G. \& Puntorieri, P., Shoreline evolution near the mouth of the Petrace River (Reggio Calabria, Italy). Proceedings of the 9th International Conference on River Basin Management, Prague, Czech Republic, 2017.

[38] Xu, J.X., Sediment flux to the sea as influenced by changing human activities and precipitation: Example of the Yellow River, China. Environmental Management, 31, pp. 328-341, 2003.

[39] Li, X., Zhou, Y., Zhang, L. \& Kuang, R., Shoreline change of Chongming Dongtan and response to river sediment load: a remote sensing assessment. Journal of Hydrology, 511, pp. 432-442, 2014.

[40] Yang, Z., Wang, T., Voisin, N. \& Copping, A., Estuarine response to river flow and sea-level rise under future climate change and human development. Estuarine, Coastal and Shelf Science, 156, pp. 19-30, 2015.

[41] Wang, H.J., Yang, Z.S., Saito, Y., Liu, J.P., Sun, X.X. \& Wang, Y., Stepwise decreases of the Huanghe (Yellow River) sediment load (1950-2005): Impacts of climate change and human activities. Global and Planetary Change, 57, pp. 331-354, 2007. 
[42] Yu, J. et al., Effects of water discharge and sediment load on evolution of modern Yellow River Delta, China, over the period from 1976 to 2009. Biogeosciences, 8(9), pp. 2427-2435, 2011.

[43] Foti, G. \& Sicilia, C.L., Analysis, evaluation and innovative methodologies to prevent coastal erosion. Proceedings of the Third International Conference on Physical Coastal Processes, Management and Engineering, Gran Canaria, Spain, 2013.

[44] Barbaro, G., Master plan of solutions to mitigate the risk of coastal erosion in Calabria (Italy): A case study. Ocean \& Coastal Management, 132, pp. 24-35, 2016. 